\title{
The analysis of $\alpha$-tocopherol and ubiquinone in rat liver
}

\author{
By A. T. DIPLOCK, J. GREEN, J. BUNYAN AND D. McHALE \\ Walton Oaks Experimental Station, Vitamins Limited, \\ Dorking Road, Tadworth, Surrey
}

(Received ${ }_{3} 3$ August 1965-Accepted 8 October 1965)

\begin{abstract}
I. A comparative study has been made of five methods of saponifying normal and vitamin E-deficient rat liver and subsequently measuring ubiquinone and $\alpha$-tocopherol. 2 . Losses of ubiquinone and $\alpha$-tocopherol occur under certain conditions, and three of the methods were judged to be unsatisfactory. Recoveries of $\alpha$-tocopherol are nearly quantitative under the conditions of 'Tošić \& Moore ( 1945 ), but methods that use large reaction times or weaker alkali destroy tocopherol, and over $50 \%$ loss can be encountered. Ubiquinone does not seem as sensitive to the time of reaction, but is sensitive to the concentration of alkali and amount of water present during saponification.
\end{abstract}

Several methods have been used for the analysis of vitamin $\mathrm{E}$ in animal and vegetable tissues. A number of problems arise in the analysis, and, in respect of vegetable oils, have been summarized in the report of the vitamin E panel of the Society for Analytical Chemistry: Analytical Methods Committee (1959); most of the findings apply with equal force to animal tissues. The problems concerned with separation of the vitamin $\mathrm{E}$ fraction of the purified extracts into its several tocopherols and the differentiation of the latter from other non-tocopherol reducing compounds and substances that are inhibitory in the colorimetric analysis are, in the main, readily solved by a combination of column and paper chromatography and need little further discussion. Satisfactory columns should be capable of giving at least $90 \%$ recovery of Io $\mu \mathrm{g} \alpha$-tocopherol (a figure that can usually be improved on when the tocopherol is in the presence of other unsaponifiable lipids). Columns prepared from Decalso $F$ of British manufacture (Permutit Ltd) are satisfactory (Diplock, Edwin, Bunyan $\&$ Green, I96I), but Decalso of US manufacture has been found to be unsatisfactory. Bro-Rasmussen \& Hjarde (I957) described an efficient column of secondary magnesium phosphate, and Bieri, Pollard, Prange \& Dam (r96I) used an alumina-zinc carbonatecelite column with good results. Silicic acid-celite columns (Draper, Bergan, Chiu, Csallany \& Boaro, 1964) and Floridin columns (Diplock, Green, Edwin \& Bunyan, I960) give low recoveries of vitamin $E$ when used with animal tissues. Paper chromatographic separation of the purified extracts (Society for Analytical Chemistry: Analytical Methods Committee, I959) can be used for all tissues, animal or vegetable.

The chief difficulty with animal tissues is the quantitative extraction of the tocopherol for analysis. The problem does not arise with vegetable oils, and this stage was accordingly not discussed in the vitamin $\mathrm{E}$ panel report (Society for Analytical Chemistry: Analytical Methods Committee, 1959). Two alternatives present themselves: either the tissue can be comminuted in some way (minced, blended with solvent, pulverized after freezing together with sodium sulphate, frozen and chopped) 
and the lipid extracted with a solvent and subsequently saponified; or the tissue is digested with alkali, partially or wholly saponified, and the tocopherol is then recovered by solvent extraction. Little information exists as to the efficiency of these methods, which have become as varied in procedure as they are numerous, for until suitable techniques for quantitative purification and separation of $\alpha$-tocopherol from the extracts became available, study of the extraction and saponification stages was methodologically unfeasible. However, these stages, especially saponification, can cause serious losses of tocopherol, unless the conditions are rigorously defined, and the provision of antioxidant conditions does not necessarily mitigate against these losses, as Lehman (1955) makes clear in his review of vitamin $\mathrm{E}$ analysis. As the problem of measuring ever smaller amounts of vitamin $\mathrm{E}$ in animal tissues becomes more pressing it becomes important to re-examine methods for its extraction from animal tissues.

The analysis of ubiquinone in tissues is methodologically linked to that of $\alpha$ tocopherol, and several workers have measured both substances in extracts derived from the same procedure. Nevertheless, ubiquinone is known to be susceptible to alkali under certain conditions, and saponification of ubiquinone-containing tissues or extracts has been stated to be hazardous (Festenstein, Heaton, Lowe $\&$ Morton, 1955).

We have carried out a comparative study of several methods of extraction of $\alpha$ tocopherol and ubiquinone from rat liver, special attention being paid to the losses that may occur during alkaline digestion.

\section{EXPERIMENTAL AND RESULTS}

We have selected five methods that are sufficiently different to provide obvious variation in analytical procedure.

Method $A$. The method of Diplock et al. (1960), in which the tissue is pulverized with acetone and anhydrous $\mathrm{Na}_{2} \mathrm{SO}_{4}$ at $-70^{\circ}$ and then extracted with acetone in a Soxhlet. The extracted lipid ( $\mathrm{g}$ or less) is saponified for $5 \mathrm{~min}$ with $2 \mathrm{ml}$ saturated aqueous KOH (Tošić \& Moore, I945) in $4 \mathrm{ml}$ ethanol containing $200 \mathrm{mg}$ pyrogallol. The method has been used for the analysis of vitamin $\mathrm{E}$ and ubiquinone in several types of animal tissue.

Method B. The method of Mervyn \& Morton (1959). The tissue is digested with $60 \%(\mathrm{w} / \mathrm{w}) \mathrm{KOH}(0.5 \mathrm{ml} / \mathrm{g}$ of tissue $)$ in the presence of ethanolic pyrogallol $(0.25 \%$, $\mathrm{w} / \mathrm{v} ; \mathrm{I} \mathrm{ml} / \mathrm{g}$ of tissue), and is then extracted with diethyl ether. The method has been used in many studies by Morton and co-workers for the determination of ubiquinone. Although it has been used semi-quantitatively for the fractionation of other lipid constituents (Morton \& Phillips, 1959), it does not appear to have been rigorously examined for vitamin $\mathrm{E}$ analysis.

Method C. The method of Draper et al. (1964), as used for rat heart and liver. The tissue is chopped and heated under reflux in the dark for $\mathrm{I} \mathrm{h}$ with $\mathrm{I} \mathrm{ml}$ of $0.25 \%$ $(\mathrm{w} / \mathrm{v})$ methanolic pyrogallol and $0.5 \mathrm{ml}$ of $60 \%(\mathrm{w} / \mathrm{v}) \mathrm{KOH}$ per $\mathrm{g}$ of tissue. After dilution with water the mixture is extracted with diethyl ether and the extract dried 
with anhydrous $\mathrm{Na}_{2} \mathrm{SO}_{4}$. The method has been used for vitamin $\mathrm{E}$ (Draper et al. 1964) and ubiquinone determination (Lee, Chiu \& Draper, I965).

Method $D$. This method has been described for $\alpha$-tocopherol analysis by Bieri et al. (1961). The tissue $\left(0 \cdot 5^{-3} \mathrm{~g}\right)$ is homogenized with $5^{-10} \mathrm{ml}$ water and mixed with an equal volume of ethanol containing 50-100 $\mathrm{mg}$ pyrogallol. To the boiling mixture is added freshly boiled $50 \%(\mathrm{w} / \mathrm{v}) \mathrm{KOH}$ (half the weight of the tissue), and heating is continued for $\mathrm{I}^{-25} \mathrm{~min}$. The mixture is cooled and extracted with hexane several times, and the hexane solution is dried over anhydrous $\mathrm{Na}_{2} \mathrm{SO}_{4}$.

Method E. This method is an alternative one to method $\mathrm{D}$, given by Bieri et al. (196I). The chopped tissue is digested in $15^{-25} \mathrm{ml}$ ethanol with $50 \%(\mathrm{w} / \mathrm{v}) \mathrm{KOH}$, without the addition of water. Water is added before hexane extraction, which proceeds as in method D.

Since, in this study, we were only concerned with the stability of $\alpha$-tocopherol and ubiquinone towards the alkali digestion and extraction process, all extracts were subsequently analysed by the same method; i.e. column chromatography on Decalso $\mathrm{F}$, followed by two-dimensional paper chromatography and colorimetric determination with the ferric chloride-dipyridyl reagent (for $\alpha$-tocopherol) and borohydride reaction (for ubiquinone) (Diplock et al. 1960, 1961).

Table r. Expt x. The analysis, by five methods, $A, B, C, D$ and $E$ (see pp. 96, 97), of normal rat liver for $\alpha$-tocopherol, ubiquinone and ubichromenol (mean values with their standard errors)

( $5 \mathrm{~g}$ samples in triplicate)

$\begin{array}{lccccc} & \text { A } & \text { B } & \text { C } & \text { D } & \text { E } \\ \alpha \text {-Tocopherol }(\mu \mathrm{g} / \mathrm{g}) & 9.7 \pm 0.15 & 9.3 \pm 0.27 & 8.7 \pm 0.55 & 4.0 \pm \mathrm{I} \cdot 04 & 7.5 \pm 0.20 \\ \text { Ubiquinone }(\mu \mathrm{g} / \mathrm{g}) & 148 \pm 3.7 & 154 \pm 0.7 & 117 \pm 8.9 & 76 \pm \mathrm{I} \cdot 2 & 92 \pm \mathrm{I} \cdot 8 \\ \text { Ubichromenol }(\mu \mathrm{g} / \mathrm{g}) & 30 \pm 1.5 & 38 \pm 3.2 & 40 \pm 3.5 & 33 \pm \mathrm{I} \cdot 5 & 49 \pm 2 \cdot 0\end{array}$

Significance of differences between methods:

$\alpha$-'Tocopherol $(\mu \mathrm{g} / \mathrm{g}): \mathrm{A}, \mathrm{B}, \mathrm{C}$ and $\mathrm{E}>\mathrm{D}^{* *} ; \mathrm{A}>\mathrm{E}^{*}$

Ubiquinone $(\mu \mathrm{g} / \mathrm{g}): \mathrm{A}$ and $\mathrm{B}>\mathrm{D}$ and $\mathrm{E}^{* *} ; \mathrm{C}>\mathrm{D}^{* *} ; \mathrm{A}$ and $\mathrm{B}>\mathrm{C}^{*}$

Ubichromenol $(\mu \mathrm{g} / \mathrm{g}): \mathrm{C}$ and $\mathrm{E}>\mathrm{A}^{* *} ; \mathrm{E}>\mathrm{D}^{* *} ; \mathrm{E}>\mathrm{B}^{*}>\mathrm{A}^{*}$

* $P<0.05$.** $P<0.01$.

Expt I. This experiment was designed to compare the efficiency of the five methods when used with normal rat liver containing vitamin $\mathrm{E}$ at the concentration usually encountered in animals given adequate diets. Twelve 6-month-old rats, which had been fed on a diet supplemented with $\alpha$-tocopherol throughout their life-span, were killed and their livers removed, combined, and minced. Fifteen $5 \mathrm{~g}$ samples were prepared and stored at $-20^{\circ}$ until required. The five methods were compared on these samples, each method being carried out in triplicate. Table I gives the results of determining $\alpha$-tocopherol, ubiquinone and ubichromenol. Methods $\mathrm{A}$ and $\mathrm{B}$ gave $\alpha$-tocopherol assays in close agreement, somewhat higher (although, in this test, not significantly so) than method $\mathrm{C}$. Method $\mathrm{E}$ gave only $77 \%$ of the amount found by method $A$, which is significantly less; and method D gave poor results compared to the other four methods. For ubiquinone, method $B$ gave the highest result, but this 
was not significantly different from the result of method $A$ : both method $A$ and method B gave significantly higher recoveries than methods C, D and E. No comment can be made on the ubichromenol results, as they may be partly affected by isomerization of the ubiquinone, as well as by loss of ubichromenol itself.

Expt 2. This experiment was designed to compare the efficacy of the five methods in analysing rat liver containing a small amount of $\alpha$-tocopherol, such as might be encountered in animals deficient in vitamin $\mathrm{E}$. Ten 6-month-old rats, which had been fed on a diet deficient in vitamin $\mathbf{E}$ during their life-span, were killed. Their livers were pooled, minced with scissors, and fifteen $5 \mathrm{~g}$ samples were taken. They were assayed in triplicate by the five methods. At the start of each saponification (methods $\mathrm{B}, \mathrm{C}, \mathrm{D}$ and $\mathrm{E}), \mathrm{I} 5 \mu \mathrm{g}$ of $\left[5-M e-{ }^{14} \mathrm{C}\right]-\alpha$-tocopherol were added to the reaction mixture. In method $A$ the labelled tocopherol was added to the acetone used for extraction (preceding saponification). After saponification and extraction, $100 \mu \mathrm{g}$ of nonradioactive $\alpha$-tocopherol was added to each extract, in order to protect the small amount of radioactive material from any further loss during the subsequent stages of analysis: by this means the isotopic results can be interpreted wholly in terms of losses during the saponification and extraction stages.

Table 2. Expt 2. $\alpha$-Tocopherol and ubiquinone, determined by five methods, $A, B, C, D$ and $E$ (see pp. 96, 97) in vitamin E-deficient rat liver (mean values with their standard errors)

( $5 \mathrm{~g}$ of liver were saponified by each method in triplicate. To each sample was added, before saponification, ${ }_{5} \mu \mathrm{g}$ of $\left[5-M e_{-}^{-14} \mathrm{C}\right]-\alpha$-tocopherol, which had a total count of $1034^{\circ}$ disintegrations/sec. Tocopherol recoveries are expressed directly as percentages of this added isotope appearing in the final tocopherol spot after paper chromatographic analysis (see p. 97))

$\begin{array}{lccccc} & \text { A } & \text { B } & \text { C } & \text { D } & \text { E } \\ \alpha \text {-Tocopherol (\% recovery) } & 95 \pm 3 \cdot 2 & 74 \pm 6 \cdot 1 & 34 \pm 3 \cdot 5 & 17 \pm \mathbf{I} \cdot 0 & 62 \pm 9 \cdot 1 \\ \text { Ubiquinone }(\mu \mathrm{g} / \mathrm{g}) & 60 \pm 3 \cdot 5 & 68 \pm \mathrm{I} \cdot 5 & 47 \pm 2 \cdot 5 & 45 \pm 3 \cdot 5 & 66 \pm 3 \cdot 0\end{array}$

Significance of differences between methods:

$\alpha$-Tocopherol ( $\%$ recovery): $\mathrm{A}>\mathrm{E}^{* *}>\mathrm{C}$ and $\mathrm{D}^{* *} ; \mathrm{B}>\mathrm{C}^{* *} ; \mathrm{A}>\mathrm{B}^{*}$

Ubiquinone $(\mu \mathrm{g} / \mathrm{g}): \mathrm{A}, \mathrm{B}$ and $\mathrm{E}>\mathrm{D}^{* *} ; \mathrm{B}$ and $\mathrm{E}>\mathrm{C}^{* *} ; \mathrm{A}>\mathrm{C}^{*}$

* $P<0.05$. * $P<0.01$.

In each analysis, paper chromatographic separation was carried out as usual. The tocopherol spot, however, was not determined colorimetrically, but its ${ }^{14} \mathrm{C}$ content was measured by scintillation counting (Nuclear Enterprises Automatic Scintillation Spectrometer). Standard radioactive $\alpha$-tocopherol was counted at the same time. In this experiment, therefore, it was possible to obtain an absolute recovery of $\alpha$-tocopherol from the saponification process. Ubiquinone assays were carried out after two-dimensional paper chromatography. Results are given in Table 2, the tocopherol recoveries being expressed directly as percentages of the original ${ }^{14} \mathrm{C}$ count obtained in the final tocopherol spot after chromatography.

Comparing first the $\alpha$-tocopherol results, method A is clearly superior to the others. However, the design of the experiment is probably biased in favour of method A, for in this method the small amount of added tocopherol is not subjected to alkaline treatment before it has been protected by extraction of the total lipid of the tissue. The 
recoveries from the other methods show important differences, showing that, even in the presence of pyrogallol, such small amounts of tocopherol are readily destroyed in the absence of lipid. The differences in the recoveries may partly depend on the speed with which the tissue is digested (cf. the clear superiority of method $\mathrm{B}$, using ethanolic $\mathrm{KOH}$, over method $\mathrm{C}$, using methanolic $\mathrm{KOH}$ ).

Method $\mathrm{B}$ and method $\mathrm{E}$ gave the best recoveries of ubiquinone in this experiment. Method A gave somewhat, although not significantly, lower results. Methods $\mathrm{C}$ and $\mathrm{D}$ gave poor recoveries.

Expt 3. In view of the probable bias in Expt 2, another attempt was made to compare the methods, whilst using small amounts of vitamin $\mathrm{E}$. The difficulty in using vitamin E-deficient tissue is that losses during saponification can be obscured by the attendant problems of paper chromatographic analysis and colorimetric assay of small amounts of tocopherol. The difficulty was overcome in the following way. Twelve 6-month-old rats, which had been fed on a diet deficient in vitamin $\mathrm{E}$ during their life-span, were each given one oral dose of roo $\mu \mathrm{g}\left[5-M e-{ }^{14} \mathrm{C}\right]-\alpha$-tocopherol (specific activity, $3.91 \mu \mathrm{c} / \mathrm{mg}$ ) and killed $24 \mathrm{~h}$ later. Their livers were pooled, minced and $5 \mathrm{~g}$ samples were assayed in triplicate. Non-radioactive tocopherol (100 $\mu \mathrm{g}$ ) was added to each sample before paper chromatographic analysis, and the tocopherol spot was separated as usual. The tocopherol was then eluted and its isotopic carbon content

Table 3. Expt 3. $\alpha$-Tocopherol and ubiquinone, determined by five methods, $A, B, C, D$ and $E$ (see pp. 96, 97) in vitamin $E$-deficient rat liver (mean values with their standard errors)

(Rats were each given $100 \mu \mathrm{g}$ of $\left[5-M e{ }^{14} \mathrm{C}\right]-\alpha$-tocopherol and killed $24 \mathrm{~h}$ later. Pooled livers were assayed in triplicate. $\alpha$-Tocopherol recoveries are given as disintegrations/sec in the tocopherol (after paper chromatography) per $\mathrm{g}$ of liver)

$\alpha$-Tocopherol (dps/g)

Ubiquinone $(\mu \mathrm{g} / \mathrm{g})$
A

B

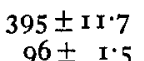

$\mathrm{C}$

$$
\begin{aligned}
& 308 \pm 17 \cdot 7 \\
& 109 \pm 1 \cdot 5
\end{aligned}
$$

D

$141 \pm 39^{\cdot 2}$

$74 \pm 4 \cdot 9$
$\mathrm{E}$

$3 \circ 3 \pm 17 \cdot 4$

$89 \pm 3 \cdot 5$

Significance of differences between methods:

$\alpha$-Tocopherol (dps/g): B and E $>D^{* *} ; A$ and $C>B$ and $E^{*}$

Ubiquinone $(\mu \mathrm{g} / \mathrm{g}): \mathrm{B}>\mathrm{A}^{* *}>\mathrm{C}$ and $\mathrm{D}^{* *} ; \mathrm{B}>\mathrm{E}^{* *}>\mathrm{D}^{* *}$

$$
* P<0.05 \text {. ** } P<0.01 \text {. }
$$

measured by scintillation counting. Table 3 gives the results. The tocopherol recoveries are expressed as disintegrations per sec (dps) per $g$ tissue. Although no absolute standard of recovery is possible in this experiment, it was possible to obtain a good approximation of an absolute recovery by repeating method $\mathrm{A}$ on three additional samples of liver, with the addition of $100 \mu \mathrm{g}$ non-radioactive carrier tocopherol at the start of the extraction stage. The tocopherol assay obtained in this series was $397 \pm 13.0 \mathrm{dps} / \mathrm{g}$ tissue, which agrees closely with the figure for method A given in Table 3 . It is thus reasonable to assume that method $A$ gives a nearly quantitative recovery of tocopherol throughout. In this experiment, method $\mathbf{C}$ gave the next best recovery, although it was somewhat (non-significantly) lower. Methods B and E gave significantly lower tocopherol recoveries (showing a loss of about 25\%) and once 
again method D was unsatisfactory. The ubiquinone results support those of earlier experiments, and method $B$ was significantly better than any of the others, although methods $\mathrm{A}$ and $\mathrm{E}$ gave reasonably good recoveries. Methods $\mathrm{C}$ and $\mathrm{E}$ showed losses of over $25 \%$.

\section{DISCUSSION}

It can be seen, from these experiments, that neither tocopherol nor ubiquinone can be recovered quantitatively from animal tissues without careful choice of conditions for the alkaline digestion and extraction stages. A few generalizations can be made. Method A was the best of the methods tried for tocopherol analysis, confirming essentially the original views of Tošić \& Moore (1945), who established that saponification must be carried out for as short a time and with as strong alkali as possible, and the procedure of the vitamin $\mathrm{E}$ panel report (Society for Analytical Chemistry: Analytical Methods Committee, 1959). The losses encountered with methods B, C and $\mathrm{E}$ are roughly proportional to the time taken for saponification, and there was no compensating advantage in the lower temperature obtained when methanolic $\mathrm{KOH}$ (method C) was used instead of ethanolic $\mathrm{KOH}$. Method $\mathrm{C}$ gave significantly higher recoveries than method $B$ when applied to tissue containing small amounts of vitamin $\mathrm{E}$ (in Expt 3, the liver contained about $0.4 \mu \mathrm{g} \alpha$-tocopherol $/ \mathrm{g}$, based on radioactivity measurements). Methods D and $\mathrm{E}$ were unsatisfactory in all three experiments. The former presumably suffers from the exceptionally large quantity of water added during saponification: this interferes with digestion, and the weak alkali must be destructive of tocopherol (a fact that has been observed by several other workers). Method E, which is described as an alternative to method D by Bieri et al. (I961), gives in fact different results. Although it is considerably better than method $D$, it does not seem to be as good as method B (Mervyn \& Morton, 1959). Bieri et al. (1961) claimed $93 \%$ recoveries of added $\alpha$-tocopherol for their saponification treatment, but it is not clear from their description which of their methods was used, nor are the conditions of the recovery experiments described. Lehman (I955) remarks on the uncertain value of 'recovery' experiments with added tocopherol.

Method B was the best method for ubiquinone, being closely followed by methods $A$ and $\mathrm{E}$. Methods $\mathrm{C}$ and $\mathrm{D}$ were unsatisfactory. When it is required to measure tocopherol and ubiquinone in the same tissue, either method A or method B is best used, although this will lead to some loss of one or other of the two substances.

It must be remembered, finally, that saponification is only one stage of a protracted analysis in which further losses can occur. Thus, although Bieri et al. (196r) claim good recoveries for their chromatographic purification of the non-saponifiable fraction, Draper et al. (1964) state that their subsequent chromatographic purification gives only a $66 \%$ recovery of $\alpha$-tocopherol.

The technical assistance of I. Muthy is gratefully acknowledged. 


\section{REFERENCES}

Bieri, J. G., Pollard, C. J., Prange, I. \& Dam, H. (I 96r). Acta chem. srand. 15, 783.

Bro-Rasmussen, F. \& Hjarde, W. (1957). Acta chem. scand. 11, 34.

Diplock, A. T., Edwin, E. E., Bunyan, J. \& Green, J. (1961). Br. F Nutr. I5, 425.

Diplock, A. T., Green, J., Edwin, E. E. \& Bunyan, J. ( I 960). Biochem. F. 76, 563.

Draper, H. H., Bergan, J. G., Chiu, M., Csallany, A. S. \& Boaro, A. V. (1964). F. Nutr. 84, 395.

Festenstein, G. N., Heaton, F. W., Lowe, J. S. \& Morton, R. A. (r955). Biochem. Y. 59, 558.

Lehman, R. W. (1955). In Methods of Biochemical Analysis. Vol. 2, p. 153. [D. Glick, editor.] New York: Interscience Publishers Inc.

Lee, D. J., Chiu, M. \& Draper, H. H. (1965). Nature, Lond., 205, 288.

Mervyn, L. \& Morton, R. A. (1959). Biochem. F. 72, 106.

Morton, R. A. \& Phillips, W. E. J. (I 959). Biochem. f. 73, 4I6.

Society for Analytical Chemistry: Analytical Methods Committee (1959). Analyst, 84, 356.

Tošić, J. \& Moore, T. (1945). Biochem. F. 39, 498. 